\title{
PERLINDUNGAN HUKUM HAK CIPTA TERHADAP KARYA TULIS PADA MEDIA INTERNET
}

\author{
Bias Lintang Dialog \\ Fakultas Hukum Universitas Kuningan \\ lintangdialog@gmail.com
}

\begin{abstract}
The cases of Copyright infringement in the form of plagiarism is done on the internet at the current often take place between them on social media, blogs and websites done by academics and non-academics by internet users. Copyright infringement is very harmful form of plagiarism is certainly given to copyright are moral rights and economic rights that need to be protected, and should receive protection. This study was conducted to examine and analyze the legal protection of the papers on the internet media if the legal consequences of copyright infringement against papers on the internet media and remedies that can be done if the creators of written works was plagiated by others . In order to achieve the objectives and obtain the data, this research using normative juridical approach qualitatively using secondary data in the form of legislation, legal documents and other legal materials. The results of this study stated that the papers found on the internet is protected by Article 12 of the Law of Copyright and reinforced by Article 25 of the Law on Information and Electronic Transactions . If plagiarism is used by a person or a group of academics then used Minister of Education Regulation No. 40 of 2010 regarding the prevention of plagiarism . Due to the law of copyright infringement can be a claim for damages, fines and or imprisonment in accordance with the rules of the Copyright Act and, where academics will be subject to administrative sanctions and when done in social media it will be socially sanctioned . Legal remedies that can be done by the creators of the paper when his rights are violated can be through settlement through litigation and non-litigation in accordance with the rules of the Copyright Act .
\end{abstract}

Keywords : Protection Law, Papers, Media Internet

\begin{abstract}
Abstrak
Kasus pelanggaran hak cipta berupa plagiarisme yang dilakukan pada media internet saat ini sering terjadi diantaranya pada media sosial, blog dan website baik dilakukan oleh akademisi maupun oleh pengguna internet non akademisi. Pelanggaran Hak Cipta berupa plagiarisme tentunya sangat merugikan mengingat pada hak cipta terdapat hak ekonomi dan hak moral yang perlu dilindungi, sehingga perlu mendapatkan perlindungan.Penelitian ini dilakukan dengan tujuan untuk mengkaji dan menganalisis perlindungan
\end{abstract}


hukum terhadap karya tulis pada media internet, serta Akibat hukum apabila adanya pelanggaran hak cipta terhadap karya tulis pada media internet dan upaya hukum yang dapat dilakukan pencipta jika karya tulisnya diguakan oleh orang lain.Guna mencapai tujuan dan memperoleh data yang sifatnya mendalam, maka penelitian ini menggunakan metode pendekatan yuridis normatif secara kualitatif menggunakan data sekunder berupa peraturan perundang-undangan, dokumen-dokumen hukum dan bahan hukum lainnya. Hasil penelitian ini menyatakan bahwa karya tulis yang terdapat pada media internet dilindungi oleh Pasal 12 Undang-Undang Hak Cipta tentang ciptaan yang dilindungi dan diperkuat oleh Pasal 25 UndangUndang Informasi dan Transaksi Elektronik mengenai perlindungan ciptaan pada media internet. Bila plagiarisme digunakan oleh seorang atau sekelompok akademisi maka digunakan Peraturan Menteri Pendidikan No 40 tahun 2010 mengenai penanggulangan plagiarisme. Akibat hukum dari pelanggaran hak cipta dapat berupa gugatan ganti rugi, denda dan atau pidana sesuai dengan aturan dalam Undang-Undang Hak Cipta dan apabila dilakukan oleh akademisi maka akan dikenai sanksi administratif serta bila dilakukan di media sosial maka akan dikenai sanksi sosial. Upaya hukum yang dapat dilakukan oleh pencipta karya tulis apabila hak nya dilanggar dapat melalui penyelesaian melalui media litigasi dan non litigasi sesuai dengan aturan dalam Undang-Undang Hak Cipta.

Kata Kunci: Perlindungan Hukum, Karya Tulis, Media Internet

\section{Pendahuluan}

HKI pada hakikatnya merupakan suatu hak dengan karakteristik khusus dan istimewa, karena hak tersebut diberikan oleh negara. Negara berdasarkan ketentuan Undang-undang, memberikan hak khusus tersebut kepada yang berhak sesuai dengan prosedur dan syarat-syarat yang harus dipenuhi. ${ }^{1}$ Menurut sifatnya, hak dalam HKI dapat digolongkan menjadi dua yaitu Hak Ekonomi (economic rights) dan Hak Moral (Moral Rights). Hak Ekonomi adalah hak untuk memperoleh keuntungan ekonomi atas kekayaan intelektual. Dikatakan Hak Ekonomi karena HKI adalah benda yang dapat dinilai dengan uang. Hak Ekonomi tersebut berupa keuntungan sejumlah uang yang diperoleh karena penggunaan oleh pihak lain berdasarkan lisensi. Hak Ekonomi itu

\footnotetext{
${ }^{1}$ Sri Rejeki Hartono dalam Sentosa Sembiring. Hak Kekayaan Intelektual dalam Berbagai Perundangan-undangan (Bandung : Yrama Widya, 2002), hlm. 13.
} 
diperhitungkan karena HKI dapat digunakan/dimanfaatkan oleh pihak lain dalam perindustrian atau perdagangan yang mendatangkan keuntungan. ${ }^{2}$

Hak moral adalah hak-hak yang melindungi kepentingan pribadi si pencipta. ${ }^{3}$ Pemilikan ata Hak Cipta dapat dipindahkan kepada pihak lain, namun Hak Moralnya tetap tidak terpisahkan dari penciptanya . Hak Moral meruakan hak yang khusus serta kekal yang dimiliki si pencipta atas hasil ciptaannya, dan hak itu tidak dapat dipisahkan dari penciptanya. ${ }^{4}$ Berdasarkan penjelasan di atas maka dapat kita ketahui bahwa Hak Cipta memiliki karakteristik yang berbeda dengan bidang HKI lainnya. Hak Ekonomi dan Hak moral adalah sifat khusus yang dimiliki oleh Hak Cipta. Oleh karena itu, perlindungan Hak Cipta memiliki ruang lingkup yang lebih luas karena melindungi Hak Ekonomi dan Hak Moral suatu ciptaan. Ciptaan yang disebutkan dalam Pasal 12 Undang-Undang Hak Cipta juga dilindungi oleh Undang-Undang Nomor 11 Tahun 2008 tentang Informasi dan Transaksi Elektronik ( UU ITE). Hal tersebut terdapat pada Pasal 1 angka 4 UndangUndang ITE mengatakan bahwa:

"Dokumen Elektronik adalah setiap informasi elektronik yang dibuat, diteruskan, dikirimkan, diterima, atau disimpan dalam bentuk analog, digital, elektromagnetik, optikal atau sejenisnya, yang dapat dilihat, ditampilkan, dan/atau didengar melalui Komputer atau Sistem Elektronik, termasuk tetapi tidak terbatas pada tulisan, suara, gambar, peta, rancangan, foto atau sejenisnya, huruf, tanda, angka, Kode Akses, simbol atau perforasi yang memiliki makna atau arti atau dapat dipahami oleh orang yang mampu memahaminya."

Pasal di atas menunjukan bahwa ciptaan yang dilindungi oleh Undang Undang Hak Cipta, dilindungi pula oleh Undang-Undang ITE. Ciptaan termasuk segala bentuk karya pencipta yang terdapat di media internet ${ }^{5}$

${ }^{2}$ Abdulkadir Muhammad. Kajian Hukum Ekonomi Hak Kekayaan Intelektual (Bandung : Citra Aditya Bakti, 2007), hlm. 23.

3 Etty Susilowati, HAK KEKAYAAN INELEKTUAL DAN LISENSI PADA HKI. (Semarang: Badan Penerbit Universitas Diponegoro Press, 2013), hlm. 52

${ }^{4}$ Ibid, hlm 54

${ }^{5}$ Ahmad M. Ramli, Cyber Law dan Haki dalam Sistem Hukum Indonesia. (Bandung: Refika Aditama, 2004), hlm. 72. 
Karya tulis merupakan salah satu materi kekayaan intelektual yang dapat dengan mudah dibajak atau di copy oleh siapa saja yang dapat mengakses internet. Mengingat betapa mudahnya orang mengunggah atau biasa disebut dengan Upload ${ }^{6}$ sebuah karya tulis kepada media internet, maka dengan mudah pula orang mengunduh (Download) $^{7}$ karya tulis tersebut. Ahmad M. Ramli mengatakan dalam bukunya mengatakan bahwa Perlu adanya harmonisasi aturan menyangkut Penggandaan Hak Cipta di media internet sebab proses copy dan paste merupakan mekanisme biasa yang sangat diperlukan dalam akses di internet termasuk pengumuman adalah termasuk publikasi melalui internet. ${ }^{8}$ Hal ini menunjukan bahwa mudahnya pengguna internet mengakses setiap informasi yang ada dan memungkinkan adanya pelanggaran terhadap Hak Cipta yang diinformasikan melalui media internet. Pada tanggal 16 Agustus 2010, situs lintangselatan.com merilis artikel yang berjudul "Plagiarisme Internet, Pencurian Karya di Dunia Maya". Situs tersebut menjelaskan bahwa 21 Artikel yang dibuat oleh lintangselatan.com diplagiat oleh situs korananakindonesia.wordpress.com. Atas artikel tentang plagiarisme yang dibuat tersebut, Koran Anak Indonesia melakukan pembelaan yang menunjukan bahwa Koran Anak Indonesia tidak melakukan plagiat terhadap lintangselatan.com walaupun telah dibuktikan dengan bukti-bukti yang kuat. ${ }^{9}$ Plagiarisme dan pelanggaran Hak Cipta di Media Internet tidak berhenti sampai disitu. Twitter sebagai media sosial pun tidak luput dari kegiatan plagiarisme, seperti yang diungkapkan oleh Ghazi Binarandi

\footnotetext{
${ }^{6}$ Upload adalah proses pengiriman atau transfer file dari media penyimpanan yang terdapat di komputer yang skalanya lebih kecil ke sebuah server atau situr web di internet. Memasang foto yang tersimpan di dalam komputer kita ke dalam blog adalah contoh kegiatan mengupload data.

${ }^{7}$ Download atau Unduh adalah menyalin atau mengkopi file dari komputer lain di internet atau jaringan ke komputer yang kita pakai. Download adalah transfer data melalui jalur komunikasi digital dari sistem yang lebih besar atau pusat (host atau server) ke sistem yang lebih kecil.

8lbid, hlm. 73.

${ }^{9}$ Avivah Yamani, http://langitselatan.com/2010/08/16/plagiasi-internet-pencurian-karyadi-dunia-maya/. diakses pada Senin, 2 Juni 2014, pukul 11.00 WIB.
} 
sebagai seseorang yang aktif memberikan informasi di twitter. Tulisannya di Twitter mengenai The Beatles dijiplak oleh akun @Beatle_INA yang tidak jelas siapa orang yang mengoprasikan akun tersebut.

Tulisan Marintan Ompusunggu, Kegiatan Anggito Abimanyu, kasus antara lintangselatan.com versus korananakindonesia.wordpress.com dan Plagiatnya akun @Beatle_INA merupakan sebagian kecil dari buku yang ditulis oleh Denidya Damayanti tersebut. Namun dari kasus tersebut dapat disimpulkan bahwa siapapun akan sangat mudah untuk menjiplak atau menggunakan karya tulisan orang lain untuk kepentingan dirinya sendiri tanpa diketahui oleh penulis dan tidak menyebutkan sumber tulisan. Kasus yang dialami Marintan Ompusunggu belum lama bergulir karena penulis baru mengetahui penjiplakan tersebut pada tanggal 25 Oktober 2013, sehingga belum ada tindakan yang dilakukan terhadap kasus ini. Oleh karena itu Penulis tertarik melakukan penelitian mengenai perlindungan hukum karya tulis yang ada di media Internet dengan judul "Perlindungan Hukum Hak Cipta terhadap Karya Tulis pada Media Internet."

\section{Perumusan Masalah}

Berdasarkan latar belakang diatas, penulis mencoba merumuskan permasalahan sekaligus merupakan pembahasan yang akan diteliti sebagai berikut:

1. Bagaimanakah perlindungan hukum terhadap karya tulis pada media Internet?

2. Bagaimana akibat hukumnya apabila terjadi suatu pelanggaran terhadap karya tulis yang dimuat di media Internet?

3. Bagaimana upaya hukum yang dapat dilakukan penulis terhadap plagiarisme yang dilakukan melalui media internet?

\section{Metode Penelitian}

Pendekatan penelitian hukum dapat digolongkan kedalam beberapa jenis yaitu Pendekatan Perundang-Undangan (Statute Approach), 
Pendekatan Kasus (Case Approach), Pendekatan Historis (Hictorical Approach), Pendekatan Perbandingan (Comparative Aproach), Pendekatan Konseptual (Conceptual Approach). Pendekatan yang digunakan oleh penulis adalah Pendekatan undang-undang (Statute Approach) karena peneliti menelaah semua undang-undang dan semua regulasi yang berkaitan dengan isu hukum yang sedang dijalani. ${ }^{10}$ Dalam peneltian ini, penulis meneliti mengenai data-data secara tertulis kemudian dianalisis menggunakan Undang-undang Hak Cipta dan Undang-undang ITE serta Peraturanperundang-undangan yang terkait, dikaitkan dengan berbagai kasus yang terjadi di dalam dunia internet khususnya pelanggaran hak cipta khususnya karya tulis yang dimuat di media Internet. Metode yang digunakan dalam pengolahan data maupun analisis data yang digunakan dalam penelitian ini adalah Kualitatif yaitu suatu metode analisis data deskripif analistis yang mengacu pada suatu masalah tertentu dan dikaitkan dengan pendapat para pakar hukum maupun berdasarkan Peraturan Perundang-undangan yang berlaku. ${ }^{11}$ Objek dalam penelitian ini adalah suatu karya tulis dalam media Internet yang kemudian diakui oleh seseorang sebagai tulisannya sendiri dan dijadikan sebuah buku atau digunakannya kembali dalam website miliknya. Undang-Undang Hak Cipta dan Undang-undang Informasi dan Transaksi Elektronik serta peraturan perundang-undangan lainnya.

\section{Pembahasan}

\section{A. Perlindungan Hukum Hak Cipta Karya Tulis pada Media Internet}

Hak Kekayaan Intelektual pada umumnya dan Hak Cipta pada khususnya termasuk pada benda bergerak yang tidak berwujud, secara hakiki hak cipta sebagai bagian dari HKI merupakan hak milik immaterial. Hak Cipta merupakan karya cipta di bidang seni, sastra dan

\footnotetext{
${ }^{10}$ Peter Mahmud Marzuki, Penelitian Hukum, (Jakarta: Kencana, 2010), hal 133

11 Soerjono Soekanto, Sri Mamudji, Penelitian Hukum Normatif Suatu Tinjauan Singkat, (Jakarta: PT Raja Grafindo Persada, 2004), hal. 13-14.
} 
bidang ilmu pengetahuan sebagai hasil yang dituangkan dari ide, gagasan, pemikiran maupun imajinasi seseorang. Seseorang pencipta senantiasa menyatu dengan hasil ciptaannya, sehingga hak yang dimiliki timbul secara otomatis. ${ }^{12}$

Hak Cipta yang digunakan pada media internet perlu dilindungi yaitu meliputi semua bentuk informasi yang tersedia secara online. Sifat perlindungan hak cipta sangat luas dan universal, prinsip dasar dalam perlindungan hak cipta adalah bahwa seorang pencipta memiliki hak untuk mengekspoitasi hasil karyanya dan pihak lain dilarang untuk meniru hasil karya yang diciptakan olehnya. Untuk dapat dimiliki oleh hak cipta, suatu hasil karya harus bersifat asli (original), bentuk ekspresi dan ada kepastian. ${ }^{13}$

Perlindungan hukum merupakan segala upaya yang dapat menjamin adanya kepastian hukum, sehingga dapat memberikan perlindungan hukum kepada pihak-pihak yang bersangkutan atau yang melakukan tindakan hukum. ${ }^{14}$ Pada dasarnya perlindungan hukum dibagi menjadi dua yaitu perlindungan hukum secara preventif dan represif. Perlindungan hukum preventif adalah bentuk perlindungan yang berfungsi sebagai pencegah adanya suatu pelanggaran. Sedangkan perlindungan hukum represif adalah perlindungan terakhir apabila suatu subjek hukum telah melakukan suatu pelangaran seperti denda dan penjara.

Perlindungan hukum hak cipta di Indonesia terdapat pada Undang-undang Nomor 19 Tahun 2000 tentang Hak Cipta (UUHC). UUHC merupakan peraturan yang didalamnya terdapat perlindungan hukum preventif dan represif. Perlindungan Hak Cipta yang bersifat preventif

${ }^{12}$ Etty Susilowati, Disampaikan pada Upacara Penerimaan Jabatan Guru Besar Dalamllmu Hukum Pada Fakultas Hukum Universitas Diponegoro, 6 Desember 2008, Hal 18.

${ }^{13}$ Ibid, hal 19.

${ }^{14}$ Hetty Hasanah, Perlindungan Konsumen dalam Perjanjian Pembiayaan Konsumen atas Kendaraan Bermotor dengan Fidusia, (http//jurnal.unikom.ac.id/vol3/perlindungan.html, 2004), hal 1. 
dalam UUHC terdapat pada Pasal 12 UUHC mengenai ciptaan-ciptaan yang dilindungi Ciptaan dalam bidang ilmu pengetahuan, seni, dan sastra, yang mencakup:

a. Buku, Program Komputer, pamflet, perwajahan (lay out) karya tulis yang diterbitkan, dan semua hasil karya tulis lain;

b. Ceramah, kuliah, pidato, dan Ciptaan lain yang sejenis dengan itu;

c. Alat peraga yang dibuat untuk kepentingan pendidikan dan ilmu pengetahuan;

d. Lagu atau musik dengan atau tanpa teks;

e. Drama atau drama musikal, tari, koreografi, pewayangan, dan pantomim;

f. Seni rupa dalam segala bentuk seperti seni lukis, gambar, seni ukir, seni kaligrafi, seni pahat, seni patung, kolase, dan seni terapan;

g. Arsitektur;

h. Peta;

i. Seni batik;

j. Fotografi;

k. Sinematografi;

l. Terjemahan, tafsir, saduran, bunga rampai, database, dan karya lain dari hasil pengalihwujudan.

Pasal 12 UUHC huruf a menyatakan bahwa buku, program komputer, pamflet, perwajahan karya tulis yang diterbitkan dan semua karya tulis lain merupakan benda yang dilindungi dalam UUHC.Karya tulis dalam hal ini merupakan salah satu dari apa yang dilindungi dalam Pasal 12 huruf a UUHC. Hal ini diperkuat oleh Pasal 12 ayat (3) yang menyatakan bahwa Perlindungan yang dimaksud oleh pasal (1) dan ayat (2), termasuk juga semua Ciptaan yang tidak atau belum diumumkan, 
tetapi sudah merupakan suatu bentuk kesatuan yang nyata, yang memungkinkan perbanyakan hal itu.

Peluang terjadinya pelanggaran hak cipta dan plagiarisme semakin besar seiring dengan canggihnya teknologi informasi, walaupun tentang hak cipta telah diatur dengan Undang-Undang Hak Cipta tidak berarti bahwa pelanggaran tersebut dapat diselesaikan dengan undang-undang yang berlaku, karena banyak hal yang tidak diatur, khususnya sifat dari teknologi internet sangat berbeda dengan teknologi dari media yang dikenal sebelumnya.

Pasal 1 angka 4 Undang-undang Nomor 11 Tahun 2008 tentang Informasi Teknologi Informasi menyatakan bahwa:

"Dokumen Elektronik adalah setiap Informasi Elektronik yang dibuat, diteruskan, dikirimkan, diterima, atau disimpan dalam bentuk analog, digital, elektromagnetik, optikal, atau sejenisnya, yang dapat dilihat, ditampilkan, dan/atau didengar melalui Komputer atau Sistem Elektronik, termasuk tetapi tidak terbatas pada tulisan, suara, gambar, peta, rancangan, foto atau sejenisnya, huruf, tanda, angka, Kode Akses, simbol atau perforasi yang memiliki makna atau arti atau dapat dipahami oleh orang yang mampu memahaminya."

Undang-undang Informasi dan Transaksi Elektronik (UUITE) mencoba mengakomodir perlindungan hukum terhadap hak kekayaan intelektual yang terdapat pada media internet. Pengertian dokumen elektronik di atas menunjukan bahwa karya tulis sebagai salah satu ciptaan yang dilindungi oleh UUHC, juga dilindungi oleh UUITE. Pasal 1 angka 4 UUITE diperkuat oleh Pasal 25 UUITE yang berisi bahwa Informasi Elektronik dan/atau Dokumen Elektronik yang disusun menjadi karya intelektual, situs internet, dan karya intelektual yang ada di dalamnya dilindungi sebagai Hak Kekayaan Intelektual berdasarkan ketentuan Peraturan Perundang-undangan. Ketentuan pada Pasal 1 angka 4 dan Pasal 25 tersebut menunjukan secara jelas bahwa segala sesuatu yang diatur oleh UUHC baik itu merupakan perlindungan hukum yang sifatnya 
preventif maupun yang bersifat represif dan terhadap segala jenis ciptaan yang berada di dunia internet, dilindungi oleh UUITE.

Perlindungan terhadap karya tulis yang bersifat represif terdapat pada BAB XIII tentang Ketentuan Pidana dalam Undang-Undang Hak Cipta. Pasal 72 UUHC menyatakan bahwa:

"Barang siapa dengan sengaja dan tanpa hak melakukan perbuatan sebagaimana dimaksud dalam Pasal 2 ayat (1) atau Pasal 49 ayat (1) dan ayat (2) dipidana dengan pidana penjara masing-masing paling singkat 1 (satu) bulan dan/atau denda paling sedikit Rp 1.000.000,00 (satu juta rupiah), atau pidana penjara paling lama 7 (tujuh) tahun dan denda paling banyak banyak Rp. 5.000.000.000,00 (lima miliar rupiah)."

Adapun isi dari Pasal 2 ayat (1) UUHC adalah:

"Hak Cipta merupakan hak ekslusif bagi pencipta atau pemegang hak cipta untuk mengumumkan atau memperbanyak ciptaannya, yang timbul secara otomatis setelah suatu ciptaan dilahirkan tanpa mengurangi pembatasan menurut peraturan perundang-undangan yang berlaku."

Membahas mengenai karya tulis sebagai suatu ciptaan, tidak dapat terlepas dari kegiatan plagiarisme. Plagiarisme berbeda dengan pelanggaran hak cipta pada umumnya. Plagiarisme diarikan sebagai false claim of author. Dalam pengertian ini, plagiarisme terjadi manakala seseorang mengambil ide, gagasan, atau karya yang dihasilkan oleh orang lain dan mengakuinya sebagai ide, gagasan, atau karyanya sendiri. $^{15}$ Menurut Prayudi, permasalahan plagiarisme akan mendapatkan perlindungan dari sosial, karena kegiatan plagiarisme selain merugikan pencipta namun juga merupakan kegiatan membodohi masyarakat. Oleh karena itu, sanksi dari masyarakat mungkin saja terjadi.

Kegiatan plagiarisme juga sering terjadi di dunia pendidikan. Perlindungan karya tulis yang dibuat oleh akademisi baik yang dimuat di dunia nyata dan di media internet di akomodir oleh Peraturan Menteri

${ }^{15}$ Prayudi Setiadharma, 2010. Mari Mengenal Haki, (Jakarta: Goodfaith Production), hal 54 
Pendidikan Nomor 17 Tahun 2010 tentang Penanggulangan Plagiat di Perguruan Tinggi. Pasal 2 Peraturan Menteri tersebut mengatakan bahwa ruang lingkup plagiarisme antara lain:

Plagiat meliputi tetapi tidak terbatas pada :

a. mengacu dan/atau mengutip istilah, kata-kata dan/atau kalimat, data dan/atau informasi dari suatu sumber tanpa menyebutkan sumber dalam catatan kutipan dan/atau tanpa menyatakan sumber secara memadai;

b. mengacu dan/atau mengutip secara acak istilah, kata-kata dan/atau kalimat, data dan/atau informasi dari suatu sumber tanpa menyebutkan sumber dalam catatan kutipan dan/atau tanpa menyatakan sumber secara memadai;

c. menggunakan sumber gagasan, pendapat, pandangan, atau teori tanpa menyatakan sumber secara memadai;

d. merumuskan dengan kata-kata dan/atau kalimat sendiri dari sumber kata-kata dan/atau kalimat, gagasan, pendapat, pandangan, atau teori tanpa menyatakan sumber secara memadai;

e. menyerahkan suatu karya ilmiah yang dihasilkan dan/atau telah dipublikasikan oleh pihak lain sebagai karya ilmiahnya tanpa menyatakan sumber secara memadai.

Sumber sebagaimana dimaksud pada ayat (1) terdiri atas orang perseorangan atau kelompok orang, masing-masing bertindak untuk diri sendiri atau kelompok atau untuk dan atas nama suatu badan, atau anonim penghasil satu atau lebih karya dan/atau karya ilmiah yang dibuat, diterbitkan, dipresentasikan, atau dimuat dalam bentuk tertulis baik cetak maupun elektronik.

Dibuat sebagaimana dimaksud pada ayat (2) berupa:
a. komposisi musik;
b. perangkat lunak komputer; 
c. fotografi;

d. lukisan;

e. sketsa;

f. patung; atau

g. hasil karya dan/atau karya ilmiah sejenis yang tidak termasuk huruf $a$, huruf $b$, huruf $c$, huruf $d$, huruf $e$, atau huruf $f$ Diterbitkan sebagaimana dimaksud pada ayat (2) berupa:

a. buku yang dicetak dan diedarkan oleh penerbit atau perguruan tinggi;

b. artikel yang dimuat dalam berkala ilmiah, majalah, atau surat kabar;

c. kertas kerja atau makalah profesional dari organisasi tertentu;

d. isi laman elektronik; atau

e. hasil karya dan/atau karya ilmiah yang tidak termasuk huruf $a$, huruf $b$, huruf $c$, dan huruf $d$.

Dipresentasikan sebagaimana dimaksud pada ayat (2) berupa:

a. presentasi di depan khalayak umum atau terbatas;

b. presentasi melalui radio/televisi/video/cakram padat/cakram video digital; atau

c. bentuk atau cara lain sejenis yang tidak termasuk dalam huruf a dan huruf $b$.

Dimuat dalam bentuk tertulis sebagaimana dimaksud pada ayat (2) berupa cetakan dan/atau elektronik. Pernyataan sumber memadai apabila dilakukan sesuai dengan tata cara pengacuan dan pengutipan dalam gaya selingkung setiap bidang ilmu, teknologi, dan seni. Segala jenis perbuatan yang telah dirumuskan dalam pasal diatas merupakan batasan-batasan plagiat menurut Permen Dikti. Namun ruang lingkup plagiarisme di media internet tidak terbatas hanya oleh akademisi saja dan untuk kepentingan akademik saja. 
Plagiarisme pun terjadi di media sosial seperti Twitter. Sebuah media sosial yang didalamnya menampilkan tulisan-tulisan baik kegiatan sehari-hari, tips, maupun informasi penting dari segala bidang seperti politik dan hukum. Perlindungan hukum mengenai tulisan yang terdapat di media sosial belum dirumuskan secara rinci dalam UUHC. UUHC lebih mengarah kepada karya tulis yang ditulis dalam blog atau website, bukan di media sosial.

Perlindungan hukum hak cipta pada umumnya dan khususnya perindungan hukum karya tulis yang dituangkan pada media internet telah dilindungi secara nyata oleh UUHC dan didukung pula oleh UU ITE serta oleh beberapa peraturan yang dikeluarkan oleh Peraturan Menteri Pendidikan. Namun, perkembangan yang terjadi di media internet belum mampu diakomodir oleh peraturan perundang-undangan yang ada saat ini. Perkembangan pada media internet yang saat ini telah merambah ke media sosial sebagai wadah mencantumkan karya tulis belum ada pengaturannya secara nyata dan belum ada sikap dari pemerintah untuk mengarah kearah untuk melindungi kepentingan tersebut. Sehingga pemerintah harus lebih serius dalam melakukan perkembangan regulasi untuk dapat mengakomodir perkembangan-perkembangan yang terjadi di media internet.

\section{B. Akibat Hukum pada Pelanggaran Hak Cipta Karya Tulis di Media Internet}

Akibat hukum adalah akibat suatu tindakan yang dilakukan untuk memperoleh suatu akibat yang dikehendaki oleh pelaku dan yang diatur oleh hukum. Tindakan yang dilakukannya merupakan tindakan hukum yakni tindakan yang dilakukan guna memperoleh sesuatu akibat yang dikehendaki hukum ${ }^{16}$ Lebih jelas lagi bahwa

\footnotetext{
${ }^{16}$ Soeroso, Pengantar Ilmu Hukum, (Jakarta: Sinar Grafika, 1996), hal. 295
} 
akibat hukum adalah segala akibat yang terjadi dari segala perbuatan hukum yang dilakukan oleh subyek hukum terhadap obyek hukum atau akibat-akibat lain yang disebabkan karena kejadiankejadian tertentu oleh hukum yang bersangkutan telah ditentukan atau dianggap sebagai akibat hukum. ${ }^{17}$ Akibat hukum sebagai akibat yang terjadi dari segala perbuatan hukum tercermin dalam sanksisanksi dalam peraturan perundang-undangan. Perlindungan hukum yang bersifat represif dalam suatu undang-undang adalah efek jera bagi subjek hukum yang melakukan suatu pelanggaran.

Undang-Undang Hak Cipta telah mengakomodir akibat hukum yang akan didapatkan oleh pelanggar hak cipta khususnya karya tulis dan plagiarisme dalam Pasal 72, BAB XIII tentang ketentuan pidana UUHC yang menyatakan bahwa :

"Barang siapa dengan sengaja dan tanpa hak melakukan perbuatan sebagaimana dimaksud dalam Pasal 2 ayat (1) atau Pasal 49 ayat (1) dan ayat (2) dipidana dengan pidana penjara masing-masing paling singkat 1 (satu) bulan dan/atau denda paling sedikit Rp 1.000.000,00 (satu juta rupiah), atau pidana penjara paling lama 7 (tujuh) tahun dan denda paling banyak banyak Rp. 5.000.000.000,00 (lima miliar rupiah)."

Pasal tersebut menjelaskan mengenai akibat hukum apabila seseorang melakukan perbuatan mengumumkan, memperbanyak ciptan orang lain. Namun tidak menjelaskan secara tegas apabila seseorang melakukan plagiarisme. Undang-Undang Hak Cipta dalam kaitannya karya tulis yang diumumkan di media internet turut dilindungi oleh Undang-Undang Informasi dan Transaksi Elektronik. Namun UU ITE tidak memberikan ketentuan pidana secara tegas terhadap pelaku pelanggaran hak cipta di media internet. UU ITE melalui pasal 25 memberikan petunjuk bahwa ketentuan pidana terhadap pelaku pelanggaran hak cipta di media internet dikenai oleh peraturan dalam UUHC itu sendiri.

\footnotetext{
${ }^{17}$ Loc cit.
} 
Pelanggaran hak cipta dan plagiarisme terhadap karya tulis di media internet bisa dilakukan oleh siapa saja dan dimana saja termasuk oleh akademisi. Akibat Hukum terhadap kegiatan plagiarisme pada karya tulis yang dilakukan oleh akademisi diatur dalam Peraturan Menteri Pendidikan No 17 Tahun 2010 tentang Penanggulangan Plagiarisme di Perguruan Tinggi. Permen tersebut mengatur mengenai karya tulis yang dilindungi hak ciptanya adalah karya yang di umumkan baik dalam bentuk tertulis maupun dalam bentuk elektronik (Pasal 1 angka 5).

Sanksi yang dapat diterima oleh plagiator di ruang lingkup perguruan tinggi diatur dalam pasal 12 Peraturan Menteri Pendidian No 17 Tahun 2010 yang isinya antara lain:

1) Sanksi bagi mahasiswa yang terbukti melakukan plagiat sebagaimana dimaksudkan dalam Pasal 10 ayat (4), secara berurutan dari yang paling ringan sampai dengan yang paling berat, terdiri atas:
a. teguran;
b. peringatan tertulis;
c. penundaan pemberian sebagian hak mahasiswa;
d. pembatalan nilai satu atau beberapa mata kuliah yang diperoleh mahasiswa;
e. pemberhentian dengan hormat dari status sebagai mahasiswa;
f. pemberhentian tidak dengan hormat dari status sebagai mahasiswa; atau
g. pembatalan ijazah apabila mahasiswa telah lulus dari suatu program.

2) Sanksi bagi dosen/peneliti/tenaga kependidikan yang terbukti melakukan plagiat sebagaimana dimaksudkan dalam Pasal 11 ayat (6), secara berurutan dari yang paling ringan sampai dengan yang paling berat, terdiri atas:

a. teguran;

b. peringatan tertulis;

c. penundaan pemberian hak dosen/peneliti/tenaga kependidikan;

d. penurunan pangkat dan jabatan akademik/fungsional;

e. pencabutan hak untuk diusulkan sebagai guru besar/profesor/ahli peneliti utama bagi yang memenuhi syarat; 
f. pemberhentian dengan hormat dari status sebagai dosen/peneliti/tenaga kependidikan;

g. pemberhentian tidak dengan hormat dari status sebagai dosen/peneliti/tenaga kependidikan; atau

h. pembatalan ijazah yang diperoleh dari perguruan tinggi yang bersangkutan.

3) Apabila dosen/peneliti/tenaga kependidikan sebagaimana dimaksud pada ayat (2) huruf $f$, huruf $g$, dan huruf $h$ menyandang sebutan guru besar/profesor/ahli peneliti utama, maka dosen/peneliti/ tenaga kependidikan tersebut dijatuhi sanksi tambahan berupa pemberhentian dari jabatan guru besar/profesor/ahli peneliti utama oleh Menteri atau pejabat yang berwenang atas usul perguruan tinggi yang diselenggarakan oleh Pemerintah atau atas usul perguruan tinggi yang diselenggarakan oleh masyarakat melalui Koordinator Perguruan Tinggi Swasta;

Secara umum, UUHC, UU ITE dan Permen Dikti telah mencoba menanggulangi kejahatan terhadap karya tulis baik pelanggaran hak cipta dan plagiarisme. Namun hal tersebut belum cukup jika dihadapkan pada perkembangan teknologi informasi saat ini. Berkembangnya sosial media di Indonesia seiring dengan maraknya plagiarisme di sosial media tersebut. Permasalahan dalam plagiarisme bukan hanya terletak pada sanksi dalam rumusan undang-undang, namun lebih condong kepada moralitas seserorang. ${ }^{18}$ Sehingga akibat hukum yang akan di dapatkan oleh plagiator di sosial media adalah sanksi moral yang beraneka ragam, mulai dari cemoohan sampai kecaman bahkan pengucilan, dan bisa ditambah sanksi administratif manakala hal tersebut dilakukan dalam institusi

\footnotetext{
18 Bandingkan dengan Prayudi Setiadharma, Mari Mengenal Haki, Goodfaith Production, 2010, hal. 60. yang menyatakan bahwa "Karya plagiat biasanya memiliki kualitas yang cenderung inferior, sehingga alih-alih memberikan nilai tambah, yang ada malah distorsi yang mengganggu. Masyarakat dalam hal ini tentunya akan dirugikan, apalagi dengan adanya kebohongandari si pelaku, sehingga sehingga secara umum plagiarisme dianggap sebagai hal yang negatif dan tidak dapat diterima.
} 
akademik ataupun pers. ${ }^{19}$ Akibat selanjutnya atas sanksi sosial tadi dapat berujung pada penutupan akun sosial media plagiator secara sepihak oleh server sosial media tersebut. Akibat-Akibat hukum yang telah terdapat di beberapa peraturan yang mengatur mengenai hak cipta karya tulis di media internet sudah sangat jelas. Namun perkembangan yang terjadi pada media internet seharusnya dapat disesuaikan juga dengan akibat hukum yang lebih kekinian. Pasalnya pengawasan terhadap plagiarisme dan pelanggaran hak cipta pada media internet sangat sulit dilakukan.

\section{Upaya Hukum Bagi Pencipta Terhadap Pelanggaran Hak Cipta Karya} Tulis di Media Internet

Maraknya kegiatan plagiarisme baik yang di lakukan di media internet maupun bersumber dari media internet merupakan hal yang sangat meresahkan. Karena jika plagiarisme merupakan permasalahan moralitas, maka maraknya plagiarisme menunjukan kualitas moral masyarakat itu sendiri. Penanggulangan terhadap pelanggaran hak cipta karya tulis dan plagiarisme bukan hanya dapat dilakukan oleh Pemerintah melalui Undang-undang. Namun dapat dicegah oleh penulis itu sendiri dan penulis dapat melakukan upaya-upaya hukum yang telah diberikan oleh UUHC.

Pencegahan yang dapat dilakukan oleh penulis dalam mengumumkan karya tulisnya di media internet baik blog ataupun website dapat dengan menggunakan fasilitas anti copy-paste yang terdapat pada opsi unggah. Hal tersebut akan mengurangi kesempatan orang lain untung melakukan plagiat terhadap karya tulis. Upaya lain yang dapat dilakukan oleh penulis terhadap karya yang akan diunggah melalui media internet adalah dengan melakukan watermarking.

\footnotetext{
${ }^{19}$ Ibid, hal 61
} 
Watermarking adalah kegiatan menyisipkan tulisan latar di setiap halaman dokumen yang dibuat. ${ }^{20} \mathrm{Hal}$ tersebut akan memberikan tanda bahwa karya tersebut merupakan milik penulis.

Penanggulangan terhadap plagiarisme adalah upaya yang dilakukan sebelum pelanggaran terjadi. Jika plagiarisme telah dilakukan oleh pelanggar hak cipta, maka penulis dapat melakukan upaya-upaya hukum sesuai dengan yang diamanatkan oleh Undang-Undang Hak Cipta.

\section{Jalur Litigasi}

\section{a. Penyelesaian Sengketa Perdata}

UU No. 19 Tahun 2002 tentang Hak Cipta dalam Bab X, Pasal 55 sampai dengan Pasal 66 mengatur ketentuan-ketentuan baru yang cukup memadai tentang penyelesaian sengketa secara perdata dengan mengajukan gugatan ganti rugi oleh pemegang hak cipta atas pelanggaran hak ciptanya kepada Pengadilan Niaga. Gugatan ganti rugi sejumlah uang tertentu yang perhitungannya dengan sendirinya harus masuk akal dan dapat dipertanggungjawabkan akuntabilitasnya. Tuntutan ganti rugi ini, jika dipandang perlu oleh UU No. 19 Tahun 2002 tentang Hak Cipta diperkenankan ditambah dengan permohonan kepada Pengadilan Niaga untuk melakukan penyitaan terhadap bendabenda yang diumumkan atau diperbanyak tanpa persetujuan dari Pencipta atau Pemegang Hak Cipta (Pasal 56 (1) UU No. 19 Tahun 2002 tentang Hak Cipta). Selanjutnya, berdasarkan pasal yang sama yaitu pada ayat selanjutnya, kepada Pemegang Hak Cipta juga diberi kewenangan untuk memohon kepada Pengadilan Niaga untuk memerintahkan penyerahan sebagian penghasilan yang diperoleh dari penyelenggaraan ceramah, pertemuan ilmiah,

${ }^{20}$ Eko Sujatmiko, Op Cit, Hal 316 
pertunjukan atau pameran karya yang merupakan hasil pelanggaran hak cipta.

BAB $X$ tentang Penyelesaian Sengketa dalam UUHC menjelaskan mengenai perbuatan-perbuatan yang dapat digugat oleh pemegang hak cipta di pasal 55 yang berisi bahwa:

Penyerahan Hak Cipta atas seluruh Ciptaan kepada pihak lain tidak mengurangi hak Pencipta atau ahli warisnya untuk menggugat tanpa persetujuannya:

a) Meniadakan nama Pencipta yang tercantum dalam pada ciptaan itu;

b) mencantumkan nama Pencipta pada Ciptaannya;

c) mengganti atau mengubah judul ciptaan; atau

d) mengubah isi ciptaan.

Pasal 56 UU No. 19 Tahun 2002 tentang Hak Cipta menetapkan sebagai berikut:

1) Pemegang Hak Cipta berhak mengajukan gugatan ganti rugi kepada Pengadilan Niaga atas pelanggaran Hak Ciptanya dan meminta penyitaan terhadap benda yang diumumkan atau hasil Perbanyakan Ciptaan itu.

2) Pemegang Hak Cipta yang berhak memohon kepada Pengadilan Niaga agar memerintahkan penyerahan seluruh atau sebagian penghasilan yang diperoleh dari penyelenggaraan ceramah, pertemuan ilmiah, pertunjukan atau pameran karya, yang merupakan hasil pelanggaran Hak Cipta.

3) Sebelum menjatuhkan putusan akhir dan untuk mencegah kerugian yang lebih besar pada pihak yang haknya dilanggar, hakim dapat memerintahkan pelanggar untuk menghentikan kegiatan Pengumuman dan/atau Perbanyakan Ciptaan atau barang yang merupakan hasil pelanggaran Hak Cipta.

Sebagaimana penyempurnaan penting lain yang dilakukan UU No. 19 Tahun 2002 tentang Hak Cipta adalah pencantuman suatu pasal baru yaitu Pasal 59. Pasal ini merupakan pasal yang menegaskan kembali hak untuk membela dari seorang pencipta atau ahli warisnya sebagai pemegang hak cipta untuk mempertahankan hak-hak moralnya dalam rangka perlindungan hak cipta seorang pencipta dengan 
mengajukan gugatan ganti rugi yang wajib diputus dalam tenggang waktu 90 hari setelah pendaftaran perkara di Pengadilan Niaga.

\section{b. Penyelesaian Perkara Pidana}

Penegakan hukum dari aspek pidana merupakan salah satu hal terpenting, sebab hal tersebut merupakan refleksi dari pelaksanaan satu kebijakan publik seperti yang tertuang dalam peraturan dalam peraturan perundang-undangan dan dengan fokus pada aparatnya. Aspek pidana ini masih menjadi hal yang sulit ditegakkan menyangkut berbagai faktor, seperti perlu disadari bahwa mengenai pelaksanaan hukum yang menyangkut berbagai tingkat penyelesaian, yaitu penyidikan, penuntutan dan pemberian keadilan.

Berdasarkan KUHAP, polisi adalah penyidik utama. Merujuk pada berbagai bidang Hak Kekayaan Intelektual (HKI), yang menjadi perhatian pokok bagi polisi adalah hak cipta dan merek. Namun, dari keduanya yang lebih menonjol adalah hak cipta berhubung mudahnya pembajakan dilakukan dan sifat pidananya yang sekarang bukan delik aduan. Untuk menyelidiki apakah sudah terjadi kejahatan pelanggaran Hak Cipta, Pasal 71 UU No. 19 Tahun 2002 tentang Hak Cipta mengatur tentang Penyidikan. Menurut isi pasal tersebut, selain Penyidik Pejabat Polisi Negara Republik Indonesia, juga Pejabat Pegawai Negeri Sipil (PPNS) tertentu di lingkungan Direktorat Jenderal Hak Kekayaan Intelektual diberi wewenang khusus sebagai penyidik seperti dimaksud dalam UU No. 8 Tahun 1981 tentang Hukum Acara Pidana, untuk melakukan penyidikan tindak pidana di bidang Hak Cipta. Penyidik Pejabat Pegawai Negeri Sipil (PPNS) tersebut berwenang: 
1) Melakukan pemeriksaan atas kebenaran pengaduan atau keterangan berkenaan dengan tindak pidana di bidang Hak Cipta;

2) Melakukan pemeriksaan terhadap pihak yang melakukan tindak pidana di bidang Hak Cipta;

3) Meminta keterangan dan barang bukti dari para pihak sehubungan dengan peristiwa tindak pidana di bidang Hak Cipta;

4) Melakukan pemeriksaan atas pembukuan, pencatatan dan dokumen lain berkenaan dengan tindak pidana di bidang Hak Cipta;

5) Melakukan pemeriksaan di tempat tertentu yang diduga terdapat barang bukti pembukuan, pencatatan dan dokumen lain;

6) Melakukan penyitaan terhadap bahan dan/atau barang hasil pelanggaran yang dapat dijadikan bukti dalam perkara tindak pidana di bidang Hak Cipta; dan

7) Meminta bantuan ahli dalam rangka pelaksanaan tugas penyidikan tindak pidana di bidang Hak Cipta.

Penyidikan oleh Penyidik Pejabat Pegawai Negeri Sipil (PPNS) dapat dilakukan setelah ada surat perintah tugas penyidikan, yaitu untuk Penyidik Pejabat Pegawai Negeri Sipil (PPNS) yang diangkat sebagai penyidik berdasarkan Keputusan Menteri Hukum dan HAM sebagaimana ditentukan dalam Penjelasan Pasal 71 (1) UU No. 19 Tahun 2002 tentang Hak Cipta.

\section{Jalur Non Litigasi / Alternative Dispute Resolution}

Pelanggaran hak cipta secara perdata oleh pihak yang merasa dirugikan hak-hak perdatanya, UU No. 19 Tahun 2002 tentang Hak Cipta memberikan kemungkinan penyelesaian sengketa secara perdata melalui arbitrase atau alternatif penyelesaian sengketa (Pasal 65 UU No. 19 Tahun 2002 tentang Hak Cipta). Mengenai pelaksanaan arbitrase atau alternatif penyelesaian sengketa, dapat dilaksanakan menurut UU No. 30 
Tahun 1999 tentang Arbitrase dan Alternatif Penyelesaian Sengketa (Lembaran Negara Tahun 1999 No. 138, Tambahan Lembaran Negara No. 3872). Alternatif penyelesaian sengketa (APS) adalah seperangkat pengalaman dan teknik hukum yang bertujuan untuk: ${ }^{21}$

1) Menyelesaikan sengketa hukum di luar pengadilan untuk keuntungan para pihak yang bersengketa;

2) Mengurangi biaya litigasi konvensional dan pengunduran waktu yang biasa terjadi;

3) Mencegah terjadinya sengketa hukum yang biasanya diajukan ke pengadilan.

Alternatif Penyelesaian Sengketa (APS) mempunyai bermacam-macam bentuk lembaga yaitu: ${ }^{22}$

a. Konsultasi: suatu tindakan yang bersifat "personal" antara suatu pihak tertentu (klien) dengan pihak lain yang merupakan pihak konsultan, dimana pihak konsultan memberikan pendapatnya kepada klien sesuai dengan keperluan dan kebutuhan kliennya.

b. Negosiasi: suatu upaya penyelesaian sengketa para pihak tanpa melalui proses pengadilan dengan tujuan mencapai kesepakatan bersama atas dasar kerja sama yang lebih harmonis dan kreatif.

c. Mediasi: cara penyelesaian sengketa melalui proses perundingan untuk memperoleh kesepakatan para pihak dengan dibantu oleh mediator.

d. Konsiliasi: penengah akan bertindak menjadi konsiliator dengan kesepakatan para pihak dengan mengusahakan solusi yang dapat diterima.

\footnotetext{
${ }^{22}$ Frans Hendra Winata, Hukum Penyelesaian Sengketa, Jakarta: Sinar Grafika, 2012, Hlm 7-8
} 
e. Penilaian Ahli: pendapat para ahli untuk suatu hal yang bersifat teknis dan sesuai dengan bidang keahliannya

Pasal 65 UUHC menyatakan bahwa sengketa Hak Cipta dapat di selesaikan dengan melalui arbitrase dan penyelesaisn sengketa diluar pengadilan (Alternative Dispute Resolution). Pengaturan mengenai penyelesaian diluar pengadilan sangatlah penting karena pada kenyataannya jalur ini lebih banyak digunakan karena waktu yang lebih efisien dan terjaganya rahasia para pihak.

Arbitrase sebagai salah satu upaya penyelesaisn sengketa diluar pengadilan memiliki beberapa manfaat antara lain: ${ }^{23}$

a. Para pihak dapat memilih hakim arbitrase yang menurut keyakinannya mempunyai ilmu pengetahuan dan latar belakang yang memadai untuk menyelesaikan sengketa yang terjadi

b. Putusan yang dihasilkan oleh arbitrase adalah final dan mengikat para pihak sehingga tidak dimungkinkan adanya upaya hukum lain, seperti banding atau kasasi, yang memakan waktu lama.

c. Proses arbitrase dari awal hingga putusan dijatuhkan dilakukan secara rahasia sehingga pihak lain tidak mengetahui sengketa yang terjadi.

Menyimak ketentuan dalam Pasal 65 UUHC dan ketentuan mengenai Arbitrase dan Penyelesaian Sengketa diluar Pengadilan berdasarkan Undang-Undang No 30 Tahun

${ }^{23}$ Yusran Isnaini, Hak Cipta dan Tantangannya di Era Cyber Space, Bogor, Ghalia Indonesia, 2009, Hal. 54 
1999 maka penyelesaian melalui arbitrase tentu harus didasarkan pada perjanjian tertulis yang dibuat oleh para pihak, baik berupa klausul yang tertera dalam perjanjian pokok maupun yang dituangkan dalam perjanjian tersendiri yang dibuat setelah timbulnya sengketa. ${ }^{24}$

Pada akhirnya, setiap upaya hukum yang dapat ditempuh oleh pencipta karya tulis, baik melalui pengadilan, arbitrase maupun penyelesaian sengketa diluar pengadilan lainnya kesemuanya memiliki keunggulan dan kekurangan masingmasing. Pencipta karya tulis yang merasa hak nya dilanggar dapat melakukan pilihan upaya hukum yang telah disediakan oleh Undang-undang Hak Cipta yang dirasa lebih dapat menguntungkan kedua belah pihak baik dari segi waktu, biaya, maupun kepercayaan terhadap lembaga penyelesaian sengketa itu sendiri.

\section{Penutup}

\section{Simpulan}

Perlindungan hukum terhadap karya tulis pada media Internet di akomodir oleh beberapa peraturan, antara lain UUHC, UU ITE dan Peraturan Menteri Pendidikan Nomor 17 Tahun 2010. UUHC mengatur mengenai perlindungan karya tulis dalam Pasal 12 ayat (1) UUHC dan diperkuat dengan Pasal 25 UU ITE sedangkan untuk larangan kegiatan plagiarisme diatur dalam Permen Dikti. Akibat hukum apabila terjadi suatu pelanggaran terhadap karya tulis yang dimuat di media Internet dapat dilihat dalam BAB XIII dalam UUHC tentang ketentuan Pidana, sedangkan plagiarisme yang dilakukan oleh perorangan dalam media sosial maka dikenakan sanksi sosial. Bagi kegiatan plagiarisme yang dilakukan oleh akademisi dan pers maka dapat dikenai sanksi administratif. Upaya hukum yang dapat dilakukan penulis terhadap

${ }^{24}$ Ibid, Hal 55 
plagiarisme yang dilakukan melalui media internet dapat melalui gugatan secara perdata, penyelesaian sengketa diluar pengadilan (Alternative Dispute Resolution) dan dapat melalui penegakan secara pidana.

\section{Saran}

Bagi pemerintah agar lebih bisa menyikapi perkembangan teknologi pada masa sekarang. Peraturan perundang-undangan seharusnya lebih bisa fleksibel dalam mengikuti perkembangan zaman sehingga kegiatan plagiarisme dapat ditanggulangi. Bagi akademisi agar hendaknya sadar bahwa kegiatan plagiarisme merupakan hal yang mencoreng nama baik institusi dan dunia pendidikan itu sendiri. Mahasiswa ataupun dosen agar tidak lupa mencantumkan nama pencipta apabila tulisan tersebut merupakan karya orang lain. Bagi masyarakat agar lebih dapat menyadari bahwa persoalan kegiatan plagiarisme menunjukan rendahnya moral masyarakat itu sendiri.

\section{Daftar Pustaka}

\section{Buku}

Isnaini, Yusran, 2009, Hak Cipta dan Tantangannya di Era Cyber Space, Ghalia Indonesia, Bogor

Marzuki, Peter Mahmud, 2010 Penelitian Hukum, Kencana, Jakarta Muhammad, Abdulkadir .2007. Kajian Hukum Ekonomi Hak Kekayaan Intelektual Citra Aditya Bakti, Bandung

Prayudi Setiadharma, 2010. Mari Mengenal Haki, Goodfaith Production, Jakarta

Ramli, Ahmad M, 2004. Cyber Law dan Haki dalam Sistem Hukum Indonesia. Refika Aditama, Bandung.

Sembiring, Sentosa. 2002, Hak Kekayaan Intelektual dalam Berbagai Perundangan-undangan Yrama Widya, Jakarta

Soekanto, Soerjono, 1986, Pengantar Penelitian Hukum, Universitas Indonesia, Jak arta. 
, dan Sri Mamuji 2004, Penelitian Hukum Normatif

Suatu Tinjauan Singkat, PT Raja Grafindo Persada, Jakarta.

Soeroso, 1996, Pengantar Ilmu Hukum, Sinar Grafika, Jakarta.

Sujatmiko, Eko, 2012, Kamus Teknologi Informasi dan Komunikasi. PT. Aksarra Sinergi Media, Surakarta.

Susilowati, Etty, 2013, HAK KEKAYAAN INELEKTUAL DAN LISENSI PADA HKI. Badan Penerbit Universitas Diponegoro Press. Semarang

Winata, Frans Hendra,2012, Hukum Penyelesaian Sengketa, Sinar Grafika, Jakarta

Undang-Undang

Indonesia, Undang-Undang Nomor 19 Tahun 2002 tentang Hak Cipta

, Undang-undang Nomor 11 Tahun 2008 tentang Informasi dan Transaksi Elektronik.

. Peraturan Menteri Pendidikan Nomor 17 Tahun 2010 tentang Larangan Plagiarisme.

Internet

www.forumpramugari.wordpress.com

www.langitselatan.com

Lain-lain

Hasanah, Hetty, 2004, Perlindungan Konsumen dalam Perjanjian Pembiayaan Konsumen atas Kendaraan Bermotor dengan Fidusia, http//jurnal.unikom.ac.id/vol3/perlindungan.html. 